\title{
Pengelolaan Sampah Plastik di Salatiga: Praktik dan Tantangan
}

\author{
Berliana Anggun Septiani¹, Dian Mita Arianie1, Via Fide Aditya Andi Risman¹, Widhi \\ Handayani $^{2 *}$, Istiarsi Saptuti Sri Kawuryan ${ }^{1}$
}

\author{
1Fakultas Ekonomika dan Bisnis Universitas Kristen Satya Wacana Jl. Diponegoro 52-60 Salatiga 50711 Jawa \\ Tengah \\ 2Fakultas Interdisiplin Universitas Kristen Satya Wacana Jl. Diponegoro 52-60 Salatiga 50711 Jawa Tengah; e- \\ mail: widhyandayani@gmail.com
}

\begin{abstract}
ABSTRAK
Peningkatan timbunan sampah, khususnya sampah plastik, merupakan masalah yang dihadapi oleh masyarakat perkotaan. Plastik tidak mudah lapuk, ringan, antikarat, dan murah, sehingga masih digunakan dalam kehidupan sehari-hari, termasuk di Salatiga. Persoalannya, selain non-biodegradabel, plastik dapat mencemari tanah dan air karena mengandung bahanbahan berbahaya, seperti hidrokarbon aromatik, ftalat, dan organoklorin. Penelitian ini bertujuan untuk menjelaskan sistem pengelolaan sampah plastik di kota Salatiga berdasarkan peran para pihak yang terlibat dalam pengelolaan sampah plastik tersebut. Studi ini menunjukkan bahwa pengelolaan sampah plastik di kota Salatiga melibatkan empat pihak, yaitu rumah tangga sebagai penghasil sampah, pemulung sebagai agen pemilah sampah, Bank Sampah dan pengepul sebagai pengolah sampah plastik, serta pemerintah sebagai pengelola sampah kota Salatiga. Saat ini, upaya pengolahan sampah di Salatiga lebih diarahkan pada sistem kumpulkan-angkut-buang, pengolahan, dan penimbunan. Pengurangan konsumsi plastik masih harus berhadapan dengan aspek sosial budaya masyarakat yang belum dapat beralih dari plastik, selain kesadaran lingkungan yang harus terus dipupuk. Berkenaan dengan itu, peran pemerintah menjadi penting untuk mengedukasi masyarakat supaya dapat memilah sampah dan mengurangi perilaku menyampah, membangun kapasitas Bank Sampah, mengelola pemulung dan pengepul, membangun sinergi antara pengepul dan Bank Sampah, serta melakukan pengolahan akhir untuk sampah-sampah yang sudah tidak dapat diolah lagi oleh Bank Sampah dan pengepul.
\end{abstract}

Kata kunci: Kesadaran lingkungan, Pemangku kepentingan, Pencemaran, Pengelolaan sampah kota, Plastik

\begin{abstract}
The increase of solid waste production is a general problem in municipality, particularly of plastic waste. The durability, light-weight, anticorrosiveness, and inexpensiveness properties of plastic make it favorable to be used in daily life, including in Salatiga. In addition to its nonbiodegradability however, plastic could lead to soil and water pollution as it contains toxic compounds such as aromatic hydrocarbons, phthalates, and organochlorine. This study aims to explain the plastic waste management in Salatiga based on the role of the stakeholders. The result shows there are four stakeholders who were involved in municipal plastic waste management in Salatiga. They were the households who generate wastes, the scavengers who sorts the wastes, Bank Sampah and collectors who have the same role in order to collect the wastes and treat the plastic wastes through reusing or recycling processes, and the government. Currently, efforts in waste treatment in Salatiga are focused on the system of collecting-tranferring-disposal, waste treatment by reuse and recycle processing, and landfilling. Reducing plastic consumption must take into account the sociocultural aspect and environmental awareness, as the people are still interested to use plastic. Finally, the role of government is central to educate the community in term of sorting activities and reducing waste production, building the capacity of Bank Sampah, and managing the role of scavengers and collectors. Other alternatives include creating synergy between the collectors and Bank Sampah, as well as ensuring final treatment of the unprocessed wastes disposed by collectors and Bank Sampah.
\end{abstract}

Keywords: Environmental awareness, Municipal solid waste management, Plastic, Pollution, Stakeholder

Citation: Septiani, B.A., Arianie, D.M., Risman, V.F.A.A., Handayani, W., dan Kawuryan, I.S. (2019). Pengelolaan Sampah Plastik di Salatiga: Praktik dan Tantangan. Jurnal Ilmu Lingkungan, 17(1), 90-99, doi:10.14710/jil.17.1.90-99

\section{Latar Belakang}

Plastik masih sering digunakan dalam kehidupan sehari-hari masyarakat di Indonesia. Selain bahannya yang tidak mahal, plastik tidak mudah lapuk, ringan, dan anti-karat (Thompson et al. 2009). Walaupun demikian, tumpukan sampah plastik dapat mengganggu lingkungan karena ia bersifat non-biodegradabel. Sifat tersebut menjadikannya penyumbang limbah terbesar yang menyebabkan kerusakan lingkungan (Asia \& Arifin, 2017). Selain mengganggu estetika, masalah yang ditimbulkan oleh plastik adalah risikonya untuk mentransfer senyawa-senyawa toksik kepada ekosistem dan mengganggu makhluk hidup di 
dalamnya karena plastik tertelan oleh mereka. Remah-remah plastik mengandung PCB (Polychlorinated biphenyl), hidrokarbon aromatik, pestisida organoklorin, ftalat, dan zat-zat lain yang memang ditambahkan saat produksi, tetapi juga menjadi bahan yang menempel dari lingkungan (Thompson et al. 2009). Berbagai upaya dilakukan masyarakat untuk menghancurkan atau membuang sampah plastik seperti menguburnya di tanah atau membakarnya, tetapi upaya-upaya tersebut menimbulkan masalah lain seperti dihasilkannya gas hasil pembakaran, penyumbatan aliran air, dan munculnya plastik ke permukaan lagi setelah ditimbun (Sahwan et al., 2005).

Menurut Jambeck et al. (2015), Indonesia berada di peringkat kedua dunia pembuang sampah plastik ke laut dengan laju 0,52 kg sampah/orang/hari atau setara dengan 3,22 MMT/tahun. Penelitian Assuyuti et al. (2018) juga melaporkan pencemaran di Kepulauan Seribu oleh sampah plastik. khususnya di Pulau Panggang dan Pulau Pramuka pada kedalaman 3m. Laporan Hendiarti (2018) menunjukkan bahwa peningkatan sampah di Indonesia mencapai 38 juta ton/tahun dan $30 \%$ dari sampah tersebut adalah plastik. Studi-studi tersebut menunjukkan bahwa tingkat konsumsi plastik oleh masyarakat kita masih tinggi dan situasi yang demikian menuntut partisipasi seluruh lapisan masyarakat dalam mengelola sampah plastik sebagai upaya mengurangi penumpukan plastik. Pemerintah telah berkomitmen untuk mengurangi sampah dengan program 3R (Reduce, Reuse, Recycle) hingga $30 \%$ sampai 2025, dan khusus untuk sampah plastik, Pemerintah menetapkan target penurunan hingga $70 \%$ pada 2025 (Hendiarti, 2018). Meskipun dinilai bermanfaat oleh masyarakat, pengusaha, maupun pemerintah, optimalisasi program 3R masih diperlukan untuk mengurangi timbunan sampah plastik (Damanhuri \& Padmi, 2010).

Pembatasan untuk menggunakan kantung plastik telah dilakukan di beberapa negara seperti Denmark, Bangladesh, Afrika Selatan, China, Belgia, dan Botswana melalui larangan dan pajak atau kombinasi keduanya (Nielsen et al. 2019). Penelitian Purwoko (2012) juga merekomendasikan supaya pemerintah mengenakan cukai bertarif tinggi pada kantong plastik guna menurunkan permintaan kantong plastik tanpa mengurangi produk domestik bruto. Pemerintahpun telah berusaha membangun green behavior masyarakat dengan menerapkan kebijakan "kantong plastik berbayar" saat konsumen berbelanja di gerai-gerai perbelanjaan. Sayangnya, selain hanya diterapkan pada ritel-ritel modern, kebijakan ini belum dapat mendorong masyarakat untuk sepenuhnya beralih dari penggunaan kantong plastik (Novianti \& Kartika, 2017).

Selain itu, minimnya pengetahuan dan penyuluhan mengenai dampak kurang terkelolanya sampah berpengaruh pada kurangnya kesadaran masyarakat dalam mengelola sampah plastik. Pengetahuan yang baik dapat menumbuhkan perilaku yang baik dalam mengelola sampah, seperti 91 yang ditunjukkan oleh ibu-ibu rumah tangga di Kaliwungu, Kabupaten Semarang (Setyowati \& Mulasari, 2013). Artinya, selain pelbagai upaya 3R dan kebijakan yang diterapkan pemerintah, edukasi terhadap masyarakat diperlukan supaya sampah plastik dapat dikelola dengan baik mulai dari tingkat rumah tangga.

Tulisan Singh \& Sharma (2016) memaparkan bahwa di India meskipun ada sistem formal pengumpulan sampah kota - termasuk plastik -, tetapi sektor informal seperti pemulung hanya mau mengumpulkan botol PET. Selain itu, metode dan teknologi daur ulang yang sudah usang merupakan salah satu tantangan dalam pengolahan sampah plastik. Selain itu, Zhang \& Wen (2014) menulis tentang konsumsi serta pengumpulan botol PET di Beijing dan pihak-pihak yang terlibat dalam konsumsi serta pengumpulannya.

Pelbagai studi tersebut memberikan kontribusi dalam kaitannya dengan pengelolaan sampah, termasuk sampah plastik. Meskipun demikian, mereka cenderung melakukan pendekatan secara terpisah-pisah dan masih terbatas dalam mengidentifikasi seluruh pihak yang terlibat dalam pengelolaan sampah. Sementara, model Integrated Sustainable Waste Management (ISWM) mendorong dilakukannya studi terhadap tiga elemennya secara integral. Ketiga elemen yang dimaksud adalah: (1) pemangku kepentingan atau stakeholder yang berkepentingan terhadap pengelolaan sampah; (2) alir pembuangan sampah, dimulai dari titik dihasilkannya hingga pengolahan atau pembuangan akhir; dan (3) sudut pandang yang melaluinya system pengelolaan ini dianalisis (Guerrero et al., 2013).

Terkait dengan stakeholder, Guerrero et al. (2013) menulis bahwa pengelolaan sampah melibatkan beberapa pihak dengan kepentingan berbeda yang berperan dalam membangun sistem pengelolaan sampah kota. Penjelasan mengenai peran stakeholder, seperti pemerintah, masyarakat, dan pihak-pihak teknis dalam pengelolaan sampah ini menjadi penting untuk menyusun model sistem pengelolaan sampah yang efektif, efisien, dan berkelanjutan (Morissey \& Browne, 2004; Guerrero et al. 2013). Oleh sebab itu, penelitian ini dilakukan untuk menjelaskan sistem pengelolaan sampah plastik di kota Salatiga berdasarkan peran para pihak yang terlibat dalam pengelolaan sampah plastik tersebut.

\section{Metode Penelitian}

Penelitian ini dilakukan di Kota Salatiga pada bulan Mei 2018 hingga Agustus 2018. Menurut Diskominfo Kota Salatiga (2017), secara administratif, Salatiga menempati wilayah seluas 5.678 Ha dan terdiri atas empat kecamatan, 23 kelurahan, 200 Rukun Warga, dan 1.081 Rukun Tetangga. Jumlah penduduk di Salatiga tahun 2016 sebanyak 186.316 orang yang tersebar di keempat kecamatan, yaitu kecamatan Argomulyo, Sidorejo, 
Sidomukti, dan Tingkir, dengan kepadatan penduduk 3.084 per $\mathrm{km}^{2}$.

Metode yang digunakan dalam penelitian ini adalah metode kualitatif. Metode tersebut digunakan karena subjek penelitian merupakan pemangku kepentingan yang terlibat dalam pengelolaan sampah, sehingga menuntut informasi yang mendalam. Perilaku manusia akan mudah dipahami jika kita memperhatikan makna dan tujuan mereka dalam melakukan tindakan atau aktivitas (Guba \& Lincoln, 1994). Meskipun demikian, karena penelitian ini merupakan studi kasus, maka kesimpulan penelitian ini tidak akan digunakan untuk kepentingan generalisasi.

Data yang dikumpulkan terdiri atas data primer dan sekunder. Data sekunder diperoleh dari literatur-literatur pendukung. Data primer dikumpulkan dengan teknik observasi serta wawancara mendalam terhadap sebelas subjek penelitian yang terdiri atas seorang pengepul, empat orang pemulung, tiga orang konsumen atau pengguna plastik (satu orang pemilik jasa binatu, satu orang mahasiswa, dan satu orang Pegawai Negeri Sipil), seorang responden dari Bank Sampah, seorang responden dari Tempat Pembuangan Akhir(TPA), dan satu responden yang bekerja sebagai staf Dinas Lingkungan Hidup (DLH) di Salatiga. Wawancara dilakukan selama rata-rata 42 menit. Guna menjaga kerahasiaan identitas responden, nama-nama mereka dalam penelitian ini tidak disebutkan. Data dianalisis dengan teknik analisis deskriptif kualitatif, lalu hasilnya disajikan secara naratif.

\section{Hasil dan Pembahasan}

\subsection{Gambaran masalah persampahan di Salatiga}

Persampahan termasuk ke dalam masalah sosial di Salatiga. Setiap tahun terjadi peningkatan volume sampah yang sayangnya tidak diikuti dengan peningkatan volume sampah terangkut. Pada tahun 2016, sampah yang dihasilkan mencapai 427 $\mathrm{m}^{3} /$ hari, namun yang terangkut hanya $297 \mathrm{~m}^{3} /$ hari (Diskominfo Kota Salatiga, 2017).

Budiana \& Maryono (2017) mencatat bahwa total timbunan sampah di kota Salatiga pada tahun 2017 mencapai 596.456,85 liter per hari. Jika dibandingkan dengan tahun sebelumnya, memang tampak adanya peningkatan volume sampah sekitar $169 \mathrm{~m}^{3}$ /hari. Penelitian Budiana \& Maryono (2017) juga menunjukkan bahwa volume sampah domestik, sebesar 327.206,72 liter/hari atau 327,206 m³/hari, lebih besar dibandingkan volume sampah non domestik sebanyak 269.250,13 liter/hari atau 269,25 $\mathrm{m}^{3} /$ hari.

Komposisi sampah yang ada di kota Salatiga selama tiga tahun terakhir disajikan pada Tabel 1. Data tersebut menunjukkan bahwa sampah plastik menempati persentase tertinggi kedua setelah sampah organik. Ini mengindikasikan bahwa penduduk kota Salatiga masih mengkonsumsi plastik, meskipun konsumsinya pada tahun 2016 sedikit menurun dibandingkan dua tahun sebelumnya. 92
Penurunan tersebut kemungkinan merupakan dampak dari diterapkannya uji coba kebijakan kantong plastik berbayar berskala nasional melalui Surat Edaran nomor SE.6/PSLB/PS/PLB.0/5/2016 yang diterbitkan tahun 2016.

Tabel 1. Komposisi sampah kota Salatiga

\begin{tabular}{clccc}
\hline \hline \multirow{2}{*}{ No } & Komposisi & \multicolumn{3}{c}{ Persentase (\%) pada tahun } \\
\cline { 3 - 5 } & & 2014 & 2015 & 2016 \\
\hline 1 & Kertas & 7,28 & 7,28 & 7,00 \\
2 & Kayu & 0,04 & 0,04 & 1,00 \\
3 & Kain & 0,13 & 0,13 & 1,00 \\
4 & Karet/Kulit & 0,20 & 0,20 & 1,00 \\
5 & Plastik & 19,65 & 19,65 & 18,00 \\
6 & Metal & 0,43 & 0,43 & 1,00 \\
7 & Gelas & 0,83 & 0,83 & 1,00 \\
8 & Organik & 70,70 & 70,70 & 68,00 \\
9 & Baterai & 0,60 & 0,60 & 1,00 \\
10 & Asbes & 0,00 & 0,00 & 0,00 \\
11 & Lain-lain & 0,10 & 0,10 & 1,00 \\
\hline
\end{tabular}

Sumber: Diskominfo Kota Salatiga (2017)

\subsection{Mengapa menggunakan plastik?}

Penggunaan barang-barang plastik, baik yang berupa perkakas rumah tangga maupun kantong plastik, oleh penduduk di Salatiga telah menjadi kebiasaan yang umum dalam kehidupan sehari-hari. Berdasarkan hasil wawancara, kantong plastik masih sering digunakan oleh para pengguna terutama untuk berbelanja dan untuk membungkus pakaian. Bahkan jika para pengguna membawa tas belanja sendiri, tetap saja mereka akan membawa pulang plastik karena makanan-makanan yang dibeli sering pula dibungkus plastik. Kantong plastik yang menumpuk biasanya digunakan untuk tempat sampah oleh para pengguna, dibakar, atau dibuang tanpa dipilah terlebih dahulu. Meskipun para pengguna tahu bahwa plastik sukar terurai secara alamiah, mereka tetap menggunakan plastik karena mudah didapatkan, murah, dan belum tergantikan oleh bahan lain.

Hasil studi ini menunjukkan bahwa kantong plastik paling berisiko menjadi sampah karena mudah didapatkan dan murah. Perkakas atau perabotan plastik, meskipun mudah diperoleh, tidak langsung dibuang karena akan digunakan terlebih dahulu selama jangka waktu tertentu dan setelah rusak baru dibuang. Meskipun ada pengguna yang menggunakan kantong plastik beberapa kali sebelum dibuang, tetapi ada juga yang masih cenderung menggunakan kantong plastik hanya sekali pakai. Selain itu, para pengguna berpendapat bahwa mereka menggunakan kantong plastik karena belum ada barang penggantinya. Di Indonesia, plastik biodegradable atau bioplastic sudah ada. Plastik ini dibuat dari pati singkong dan dapat terurai dalam waktu 3-6 bulan, tetapi harganya lebih mahal ketimbang plastik konvensional dan produksinya masih terbatas (Kamsiati et al., 2017). Bagaimanapun, perilaku merupakan faktor yang penting dalam kaitannya dengan produksi sampah. Bahkan jika bioplastic dapat diproduksi massal, perilaku mengkonsumsi plastik secara terus menerus tetap menambah volume sampah. Jadi, produksi 
bioplastic tetap perlu diimbangi dengan perilaku yang diarahkan untuk mengurangi konsumsi plastik.

\subsection{Alur pengolahan sampah plastik}

Studi ini mengidentifikasi beberapa pihak yang terlibat dalam sistem pengelolaan sampah berdasarkan perannya, yaitu (1) konsumen pengguna plastik; (2) pengelola Bank Sampah; (3) pemulung dan pengepul sampah; serta (4) pemerintah, melalui Dinas Lingkungan Hidup. Mengingat bahwa sampah domestik dihasilkan oleh rumah tangga, maka masyarakat berperan sebagai agen pengolah sampah yang pertama, utamanya dalam memilah sampah.

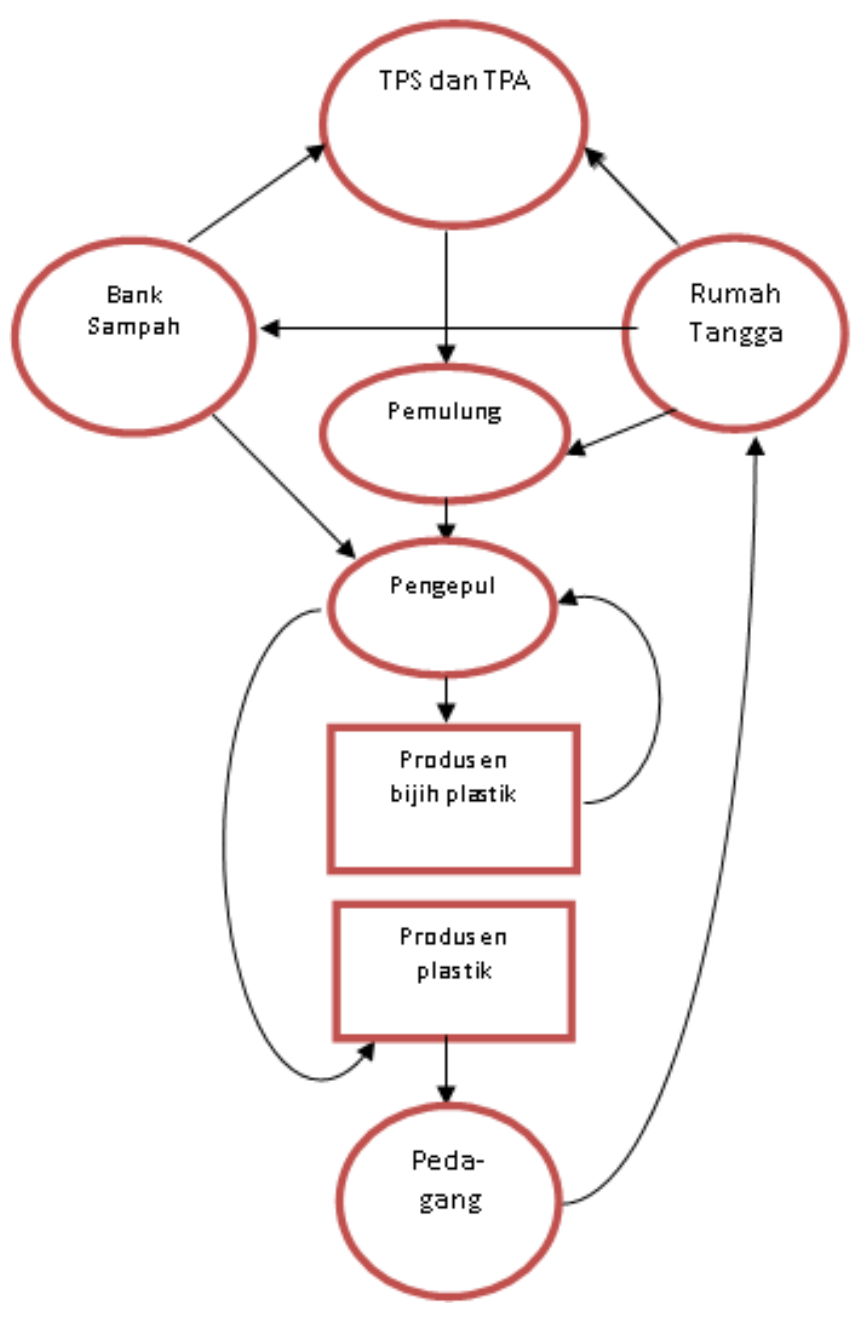

Sumber: Hasil wawancara (diolah)

Gambar 1. Alur Pengolahan Sampah Plastik di Salatiga

Gambar 1 menyajikan alur pengolahan sampah plastik di kota Salatiga. Tahap pertama pengolahan sampah plastik dimulai dari rumah tangga yang merupakan penghasil sampah. Umumnya, masyarakat masih membuang sampah tanpa memisahkan sampah dapur dari plastik, kaleng, dan kaca. Berdasarkan pengamatan dan hasil wawancara, sampah-sampah rumah tangga biasanya dikumpulkan oleh pengangkut sampah keliling yang akan membawanya ke Tempat Pembuangan Sementara (TPS). Meskipun demikian, ada pula rumah tangga yang langsung membuang sampah ke TPS, dan ada yang sampahnya diambil oleh pemulung. Sampah di TPS selanjutnya akan diangkut ke Tempat Pembuangan Akhir (TPA). Di TPS dan TPA, sampah akan dipilah oleh pemulung yang akan menjualnya kepada pengepul. Meskipun demikian, ada pula anggota masyarakat yang sudah mau memilah sampah lalu mengumpulkannya ke Bank Sampah. Jika tidak ada usaha pengolahan plastik, oleh pengelola Bank Sampah, sampah plastik tersebut akan dijual kepada pengepul.

Para pemulung mengumpulkan kantong plastik berdasarkan warnanya, yaitu bening (tidak berwarna) atau yang berwarna, dan botol-botol plastik. Kantong plastik yang dikumpulkan oleh pengepul selanjutnya akan disortir oleh pengepul, karena pengepul hanya mengumpulkan sampah plastik dari jenis PP dan HDPE. Menurut Putra \& Yuriandala (2010), plastik propilen (PP) memiliki titik cair tinggi, lebih tahan terhadap bahan kimia, dana mat sesuai digunakan untuk menyimpan makanan, minuman, dan obat. Sementara, plastik HDPE (High Density Polyethylene) sering digunakan untuk membuat botol untuk kemasan detergen, susu, dan pemutih. Biasanya plastik PP didaur ulang menjadi sikat dan sapu, sedangkan HDPE dapat didaur ulang menjadi ember dan pipa.

Plastik-plastik yang dikumpulkan pengepul selanjutnya akan dijual ke pabrik penghasil bijih plastik. Setelah diolah, bijih plastik akan dibeli lagi oleh pengepul yang akan menjualnya ke pabrik pembuat barang-barang plastik. Akhirnya, plastik daur ulang tersebut akan kembali lagi kepada pengguna.

\subsection{Peran pengolah sampah plastik}

Para pengolah sampah plastik dalam hal ini merupakan sektor informal dan sektor formal yang terdiri atas pemulung. pengepul, pengelola Bank Sampah, dan pemerintah. Pengguna plastik tidak dijelaskan di sini, karena peran mereka dalam pemilahan sampah telah diuraikan pada bagian sebelumnya.

\section{a. Pemulung}

Empat pemulung yang menjadi responden terdiri atas seorang pemulung yang menjadi penanggung jawab TPS dan tiga pemulung yang tidak mengelola TPS. Mereka melakukan pekerjaan ini untuk mendapatkan penghasilan, baik sebagai penghasilan tambahan atau penghasilan utama. Pemulung pertama yang diwawancarai melakukan pekerjaannya berdasarkan kesepakatan dengan ibuibu rumah tangga. Ia mengambil sampah setiap dua hari sekali dari 65 rumah, tetapi sampah-sampah tersebut tidak selalu dibuang ke TPS. Sampahsampah yang memiliki nilai jual tinggi seperti kardus, buku, botol plastik dan kaleng, dikumpulkan terlebih dahulu. Kantong plastik tidak termasuk ke dalam daftar sampah yang dipulungnya karena harga jualnya terlalu rendah dan hanya membuang waktu serta tenaga yang dikeluarkannya. Barang-barang yang sudah dikumpulkan tersebut dijual kepada 
pengepul sekali tiap bulan, sedangkan sampahsampah yang dianggap tidak memiliki nilai jual dibuangnya setiap dua hari sekali.

Pemulung kedua yang diwawancarai lebih suka mengumpulkan kardus karena memulung kardus dinilai lebih menguntungkan dibandingkan memulung plastik. Kantong plastik campur (selain bening) yang dipulungnya hanya dihargai Rp. 400,00 per kg, dan kantong plastik bening hanya bisa dijual Rp. 1000,00 per kg, sementara dengan kardus ia dapat memperoleh harga Rp 1200,00 - 1300,00 per kg. Pola memulung seperti ini juga dilakukan oleh pemulung ketiga. Bedanya, pemulung ketiga ini akan mencari jenis sampah dengan nilai jual paling tinggi, misalnya adalah besi-besi tua. Pemulung keempat memulung berbagai macam sampah, baik plastik, karet, dan kaleng. Pemulung terakhir ini mengumpulkan berbagai macam sampah untuk disimpan terlebih dahulu dan dijual saat harganya naik. Selain itu, penyimpanan dilakukan untuk mengumpulkan sampah sebanyak-banyaknya supaya menguntungkan saat dijual. Sebagai contoh, untuk plastik, pemulung terakhir ini akan menjualnya setelah disimpan kurang lebih 6 bulan.

Tabel 2. Harga jual sampah berbasis plastik

\begin{tabular}{clcc}
\hline \hline No & \multicolumn{1}{c}{$\begin{array}{c}\text { Jenis } \\
\text { Barang }\end{array}$} & $\begin{array}{c}\text { Jenis } \\
\text { plastik }\end{array}$ & $\begin{array}{c}\text { Harga jual per kg } \\
\text { (Rp) }\end{array}$ \\
\hline 1 & Ember & HDPE & 3500 \\
2 & Mainan & HDPE & 1600 \\
3 & Naso & HDPE & 4000 \\
4 & Botol plastik & LDPE & 3000 \\
5 & Botol infus & LDPE & 3500 \\
6 & Karpet & LDPE & 500 \\
7 & PE & PE & $3000-8000$ \\
8 & Paralon & PS & 700 \\
9 & PP & PP & 2200 \\
10 & Ember Hitam & PVC & 3000 \\
11 & Ember warna & PVC & 3500 \\
12 & Kaleng & PVC & 1600 \\
13 & Kulit kabel & PVC & 1.800 \\
14 & Tembaga kabel & PVC & 55.000 \\
15 & Sandal & PVC & 1.200 \\
\hline Sumber: Hasil wawancara (diolah) &
\end{tabular}

Hasil wawancara dengan para pemulung tersebut menunjukkan bahwa para pemulung tidak semuanya berminat untuk mengumpulkan plastik karena kurang menguntungkan bagi mereka. Bahkan seandainya mereka memulung plastik, hanya barang tertentu yang mereka pilih, utamanya yang bernilai jual cukup tinggi. Beberapa barang berbasis plastik yang biasa dikumpulkan oleh para pemulung disajikan pada Tabel 2. Tampak bahwa plastik-plastik yang dikumpulkan lebih banyak dalam wujud barang atau perabotan. Kantong plastik kurang diminati oleh para pemulung karena harganya rendah. Hasil ini sesuai dengan laporan Singh \& Sharma (2016) yang menulis bahwa kantong plastik dan plastik berkualitas rendah berukuran kurang dari 20 mikron tidak diminati oleh pemulung karena tidak menguntungkan. Artinya, mengingat bahwa sampahsampah yang tidak diambil oleh pemulung pada akhirnya dibuang ke TPA, akhirnya sampah plastik tetap membebani TPA.

\section{b. Pengepul plastik}

Umumnya, pengepul membeli sampah plastik dari pemulung. Meskipun demikian, tidak semua pengepul membeli plastik dari para pemulung. Pengepul yang kami wawancarai tidak bersedia membeli sampah plastik dari para pemulung, karena grade sampah dari rumah tangga yang menurutnya tidak memenuhi standar. Menurutnya, sampah pabrik cenderung lebih berkualitas baik, bersih dan tidak bau. Sampah plastik yang berkualitas rendah, jika diolah menjadi bijih plastik hingga menjadi produk, menghasilkan produk yang tidak memenuhi standar SNI. Inilah alasan mengapa responden kami memilih untuk mengolah sampah plastik dari pabrik alih-alih sampah plastik dari rumah tangga. Meskipun demikian, ia merasa semakin kesulitan untuk mendapatkan sampah plastik dari pabrik karena 1) program less plastic, 2) kompetisi antar pengepul plastik, 3) sistem jual beli sampah menggunakan sistem lelang dan kontrak, yang pemenangnya adalah mereka yang berani membeli sampah plastik dengan harga tertinggi.

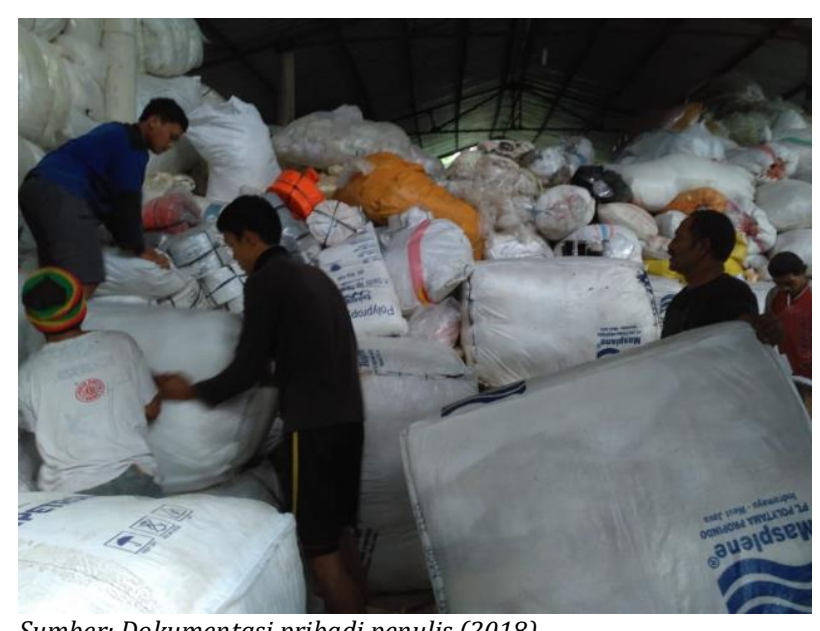

Sumber: Dokumentasi pribadi penulis (2018)

Gambar 2. Aktivitas pengepul sampah

Setelah membeli sampah plastik dari pabrik, pengepul akan memilah sampah tersebut berdasarkan jenis plastiknya, yaitu HDPE atau PP (Gambar 2.). Setelah dipilah, pengepul akan menjualnya ke Solo, yaitu ke pabrik yang mendaur ulang plastik menjadi bijih plastik. Bijih plastik hasil daur ulang plastik tersebut, yaitu bijih plastik PE dan PP, dapat dilihat pada Gambar 3. Kedua jenis bijih plastik ini dapat dibedakan secara visual lewat warnanya. Butiran plastik PE berwarna putih, sedangkan butiran plastik PP tidak berwarna.

Setelah diolah menjadi bijih plastik, pengepul akan membeli bijih plastik tersebut dan menyalurkannya kepada pabrik penghasil barangbarang plastik untuk dibuat menjadi pelbagai perabotan plastik. Pekerjaan mengepul tersebut, yang diawali dengan memulung, telah dilakukan secara turun-temurun. Meskipun pekerjaan ini dimaksudkan untuk memperoleh keuntungan, namun menurut responden, secara tidak langsung 
aktivitas ini membantu pemerintah dalam mengurangi sampah plastik di Indonesia. Adanya aktivitas pengolahan bijih plastik, dapat mengurangi volume sampah yang pada akhirnya dibuang ke TPA. Pengurangan volume sampah tersebut juga dibarengi dengan recycle/daur ulang, karena produsen barang plastik mendapat bahan baku dari pengepul.

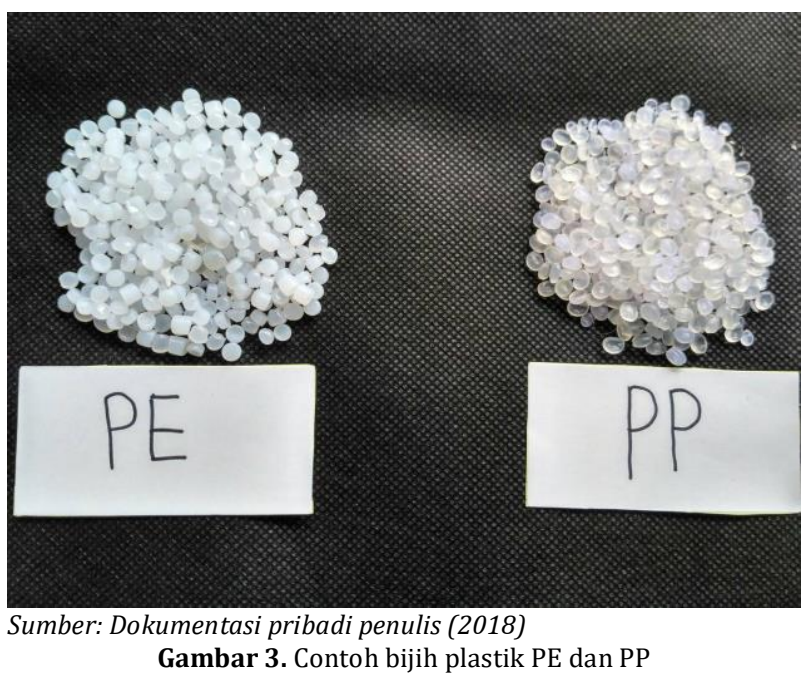

\section{c. Bank Sampah}

Bank Sampah juga menjadi bagian dari pengolahan sampah yang sudah dijumpai di berbagai kota. Sebagai suatu komunitas yang dibangun oleh masyarakat di kawasan Kota Salatiga, Bank Sampah bertujuan untuk mengurangi masalah lingkungan yang berada di Kota Salatiga. Salah satu responden yang diwawancarai adalah pengurus dari salah satu Bank Sampah di Salatiga yang didirikan pada 2013. Didirikannya Bank Sampah di Blotongan tersebut didorong oleh keprihatinan atas kekurangpedulian masyarakat setempat akan kebersihan lingkungan. Sebelum adanya Bank Sampah, masyarakat sering membuang sampah ke sungai atau membakar sampah. Akibatnya, saat hujan deras sampah-sampah tersebut terbawa arus menuju pemukiman tetangga dan situasi ini dikeluhkan oleh warga di pemukiman tetangga. Namun oleh inisiatif salah satu petugas kebersihan di Blotongan, sampah dapur dipilah dari sampah-sampah plastik dan dikomposkan di dalam lubang berukuran $1 \times 1 \mathrm{~m}^{2}$. Sementara sampah plastik dikumpulkan terlebih dahulu untuk dijual, sampah jenis lainnya yang sulit diolah (pecahan kaca, styrofoam, dll) dibuang ke TPS. Menurut petugas kebersihan tersebut, proses ini bahkan mampu mengurangi presentase sampah yang harus dibuang ke TPS sebesar $70-75 \%$ dari total sampah yang berada di lingkungan tersebut. Sistem pemilahan dan pengelolaan inilah yang akhirnya berkembang menjadi Bank Sampah.

Tujuan dasar dari pendirian Bank Sampah, menurut responden, adalah memberikan edukasi kepada masyarakat sekitar agar dapat memilah sampah rumah tangga masing-masing sesuai jenisnya. Selanjutnya, sistem yang diterapkan Bank Sampah makin berkembang. Manfaat ekonomis yang diterima oleh nasabah bukan hanya berupa upah 95 pengambilan sampah, namun juga dalam bentuk tabungan. Nilai tabungan mereka meningkat dengan semakin banyaknya sampah yang mereka kumpulkan. Tabungan tersebut biasanya akan diambil sesudah lewat satu tahun atau pada saat liburan.

Bank Sampah di Blotongan memiliki lima divisi yang dibagi menjadi Divisi Pengolahan Anorganik, Divisi Pengolahan Organik, Divisi Jual Beli, Divisi Penanaman, dan divisi yang terbaru adalah Divisi Fermentasi Pakan Ternak. Salah satu divisi, yaitu Divisi Pengolahan Anorganik, mengolah sampah melalui pembuatan kerajinan yang kemudian diperjual belikan lewat pameran dan pada kunjungan. Bahan baku kerajinan beraneka ragam dan hanya untuk menghasilkan barang yang tidak akan sama antara satu dan yang lainnya. Plastik dan kaleng merupakan bahan yang sering digunakan untuk membentuk kerajinan tangan, terutama mobil kuno yang juga menjadi ikon produksi kerajinan di Bank Sampah ini.

Dampak positif yang dirasakan oleh Bank Sampah adalah adanya kunjungan-kunjungan dari lembaga pendidikan informal maupun formal seperti pondok pesantren, PAUD, hingga perguruan tinggi. Kunjungan dari pihak luar tersebut biasanya diisi dengan pengenalan divisi dan study visit ke tempat pengolahan sampah, seperti tempat pengomposan dan penanaman pohon. Para pengunjung juga belajar membuat kerajinan tangan dan menanam pohon menggunakan kompos dari sampah.

Namun demikian, Bank Sampah ini menghadapi pelbagai persoalan berupa (1) hasil pengolahan sampah belum dapat memberikan keuntungan untuk menjamin keberlangsungan aktivitas Bank Sampah; (2) dukungan dari pemerintah masih perlu dioptimalkan; dan (3) kurangnya tempat untuk melakukan pengolahan sampah. Situasi-situasi tersebut menyebabkan Bank Sampah kurang optimal dalam melakukan aktivitas, sehingga sampah-sampah plastik tidak lagi diolah tetapi dijual kepada pengepul.

\section{d. Pemerintah}

Responden yang mewakili pemerintah sebagai sumber informasi untuk penelitian ini adalah staf Dinas Lingkungan Hidup (DLH) dan staf TPA. Hasil wawancara dengan responden memberikan gambaran bahwa pemerintah telah berupaya untuk mengelola sampah kota Salatiga. Salah satu upaya yang dilakukan adalah menyediakan sarana pengangkutan, penampungan, dan pengolahan sampah.

Sarana pengangkutan sampah yang dimaksud meliputi enam dump truck, sebelas arm roll truck, tiga truk L300, 11 gerobak motor sampah, satu sweeper (truk penyedot debu), dan satu jembatan timbang. Sampah yang diangkut oleh truk sampah terdiri atas bermacam-macam jenis, seperti sampah pasar dan sampah lainnya. Sampah pasar biasanya diolah menjadi kompos. Tetapi, TPA belum menjual kompos tersebut kepada masyarakat, sehingga kompos tersebut diberikan sebagai subsidi ke 
pengelola taman-taman kota di Salatiga, bank-bank sampah, atau masyarakat yang membutuhkan kompos dengan terlebih dahulu mengirimkan surat. Sampah yang tidak diolah menjadi kompos biasanya diambil oleh pemulung untuk pakan ternak sedangkan sampah yang sudah dianggap tidak memiliki nilai jual biasanya akan diangkut oleh truk sampah dari TPS ke TPA di Ngronggo.

TPA Ngronggo memiliki luas sekitar 5 hektar dan digunakan untuk menimbun sampah dengan sistem landfill. Dalam sehari, penimbunan sampah di TPA Ngronggo diperkirakan bisa mencapai 70 ton. Bahkan timbunan sampah sudah memenuhi bak penampungan yang dibuat oleh pemerintah di TPA hanya dalam kurun setahun.

Sampah plastik termasuk sampah yang masih mendominasi komposisi sampah di TPA Ngronggo jika dibandingkan sampah-sampah lain. Meskipun demikian, pemerintah belum dapat mengolah plastik. Guna mengurangi plastik, ada lebih dari 50 orang pemulung dan pengepul di TPA yang mengumpulkan plastik-plastik tersebut. Selain itu, pemerintah juga mengubur sampah tiap tiga bulan. Sampah-sampah yang ditimbun tersebut tidak dipilah-pilah tetapi tercampur menjadi satu. Biasanya, penimbunan dengan tanah dapat membuat sampah-sampah membusuk atau setidaknya tidak nampak lagi ke permukaan tanah. Namun, sampah plastik masih sering muncul ke permukaan karena tidak dapat terurai. Situasi tersebut mendorong pemerintah berencana membangun gedung pengayakan sampah pada tahun 2018, terlebih karena di TPA sudah ada mesin pengayak sampah yang siap dioperasikan untuk memilahkan sampah. Nantinya jika sudah beroperasi, plastik-plastik dapat dikumpulkan lalu dijual kepada pengepul.

TPA Ngronggo juga menghasilkan gas metan yang sudah diujicoba sebagai bahan bakar kompor di salah satu rumah di sekitar TPA. Ujicoba tersebut sudah berhasil dilakukan selama dua tahun dan masakan yang dihasilkan tidak berbau sampah. Walaupun demikian, ada kesulitan untuk mengontrol pipa saluran gas karena pipa tersebut ditanam di dalam tanah. Penyaluran gas ke warga lain di sekitar TPA juga belum dapat dilakukan karena harus menunggu volume gas memadai untuk disalurkan ke rumah-rumah. Salah satu persoalan yang dihadapi TPA adalah air lindi karena air lindi dari TPA mengalir ke pemukiman penduduk, terutama pada musim hujan. Jika demikian, tidak jarang penduduk setempat mengeluh kepada TPA. Pelbagai upaya tersebut, baik penambahan fasilitas pengangkut dan pengolah sampah maupun upaya penimbunan sampah dengan tanah dilakukan untuk mempertahankan Adipura.

Menurut responden dari DLH, pemerintah terus mengupayakan pendirian bank-bank sampah di tiap desa untuk mengurangi volume sampah dan setiap bulan ada pertemuan dengan pengelola bank sampah untuk bertukar pikiran. Upaya pemerintah juga dilakukan dengan mengadakan TPS 3R di beberapa tempat seperti di Kalibening, Grogol, dan 96
Jalan Baru. Beberapa TPS tersebut sudah diberi fasilitas berupa composter, supaya sudah ada pengolahan terlebih dahulu sebelum sisa sampah diangkut ke TPA.

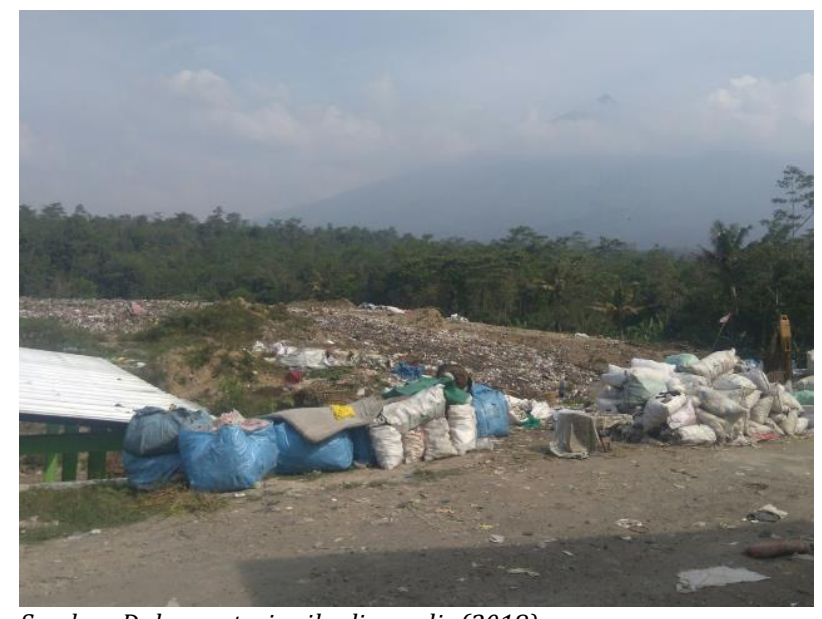

Sumber: Dokumentasi pribadi penulis (2018)

Gambar 4. Timbunan sampah di TPA Ngronggo

\subsection{Pembahasan}

Studi ini menunjukkan bahwa sampah kota Salatiga didominasi oleh sampah organik dengan persentase sekitar 70\%, plastik sekitar 20\%, dan sisanya adalah kardus, kertas, kain, kayu, dan sebagainya. Jika dibandingkan dengan China yang juga pengkonsumsi plastik, sampah organik di kotakota di China sedikitnya mencapai 44\% dan maksimum 73,70\%, sedangkan sampah plastik berada dalam rentang yang lebar, antara 3\% hingga 19,98\% (Zhang et al. 2010). Sementara, di Kuala Lumpur persentase sampah organik berada dalam rentang 22,36\% hingga 54,04\%, dan sampah plastik 8,91\% sampai 21,62\% (Kathirvale et al. 2003 dalam Latifah et al. 2009). Komparasi tersebut mengindikasikan bahwa sampah organik menempati porsi terbesar dalam komposisi sampah kota. Kebanyakan sampah organik adalah sampah dapur dan persentasenya yang tinggi menggambarkan preferensi masyarakat yang lebih banyak mengkonsumsi pangan segar dan pangan yang belum diolah.

Laporan Budiana \& Maryono (2017) menunjukkan bahwa penumpukan sampah di Salatiga disebabkan oleh perbedaan manajemen pengelola sampah (pemerintah sebagai pengolah dan masyarakat sebagai penimbun sampah) dan kurang teraturnya penjadwalan dalam pengangkutan sampah kota. Walaupun demikian, perilaku masyarakat yang suka menggunakan plastik menjadi salah satu faktor yang mempengaruhi penumpukan sampah plastik, selain sistem pengelolaan sampah yang belum optimal. Penggunaan kantong plastik, utamanya dalam transaksi jual beli, telah menjadi kebiasaan. Baik penjual maupun pembeli sudah saling tahu mengenai kebiasaan tersebut dan menerimanya sebagai suatu kepantasan. Dalam hal ini, pembeli dapat menolak kantong plastik jika ia sudah membawa tas sendiri sebelum berbelanja dan 
dengan demikian mengurangi konsumsi kantong plastik. Meskipun demikian, pengakuan para pengguna plastik menunjukkan bahwa konsumsi kantong plastik telah menjadi kebiasaan yang tampaknya sukar ditinggalkan, bahkan meskipun mereka bisa menggantinya dengan tas kain. Ini menunjukkan bahwa perilaku konsumtif terhadap plastiklah yang mendorong penumpukan plastik, seperti dicatat oleh Anderson (2010) bahwa penyampahan cenderung disebabkan oleh konsumerisme dan perilaku menyampah tanpa dikenakan biaya pembuangan.

Sementara itu, rumah tangga belum terbiasa memilahkan sampah menurut jenisnya. Situasi ini juga dijumpai di China (Zhang et al. 2010), dimana masyarakat belum terbiasa memisahkan sampah dengan menggunakan kantong yang berbeda-beda warnanya sesuai jenis sampah. Mereka yang memilahkan sampah biasanya adalah anggota Bank Sampah dan mendapatkan uang dari penjualan sampah tersebut. Penelitian Utami et al. (2008) menunjukkan bahwa partisipasi masyarakat dalam pemilahan sampah dipengaruhi oleh tingkat pendidikan, jenis kelamin, dan persepsi warga. Perempuan dan orang yang lebih tinggi tingkat pendidikan serta lebih baik persepsinya mengenai kebersihan lebih mau berpartisipasi dalam memilah sampah. Aspek-aspek tersebut merupakan persoalan sosiokultural dalam pengelolaan sampah kota, sebagaimana dicatat oleh Guerrero et al. (2013), dan Marshall \& Farahbakhsh (2013).

Sejauh ini pemerintah berusaha mengatasi masalah persampahan dengan mendorong program 3R dan menerapkan sistem kumpulkan-angkutbuang. Mengenai 3R, pemerintah telah bekerja sama dengan bank-bank sampah guna mendorong masyarakat untuk berpartisipasi mengurangi, menggunakan, dan mendaur ulang sampah. Bank Sampah memberikan kesempatan untuk meningkatkan partisipasi masyarakat dalam pemilahan sampah sekaligus meningkatkan kesadaran lingkungan. Budiana \& Maryono (2017) melaporkan bahwa di Salatiga telah beroperasi 33 Bank Sampah yang jumlahnya akan terus ditingkatkan demi mengolah sampah untuk mempertahankan Adipura. Meskipun demikian, tidak semua sampah plastik dapat diolah kembali oleh Bank Sampah untuk menjadi produk kerajinan tangan.

Situasi seperti itu menyebabkan kehadiran sektor informal, seperti pemulung dan pengepul sampah, menjadi penting. Peran pemulung dalam pengelolaan sampah di negara-negara berkembang dilaporkan juga oleh Zhang et al (2010), Marshall \& Farahbakhsh (2013), Zhang \& Wen (2014). Pemerintah juga mengandalkan peran pemulung dan pengepul untuk mengumpulkan plastik karena belum dapat mengolah sampah plastik. Sayangnya, tak banyak pemulung yang berminat mengumpulkan plastik karena nilai jualnya rendah seperti yang ditulis oleh Singh \& Sharma (2016). Bagaimanapun juga, perlu dicatat bahwa memulung sampah 97 merupakan pekerjaan yang dilakukan untuk mencari penghasilan alih-alih untuk menciptakan lingkungan bersih, dan karenanya hanya membantu dalam pemilahan sampah. Di perkotaan, sampah baru akan diperhatikan jika kebutuhan dasar masyarakatnya sudah terpenuhi atau jika tumpukan sampah menimbulkan masalah yang mengganggu kesehatan masyarakat dan upaya pemenuhan kebutuhan dasar tersebut (Marshall \& Farahbakhsh, 2013). Allaby (2000) mencatat bahwa keamanan secara ekonomi diperlukan jika perhatian masyarakat hendak dialihkan pada persoalan-persoalan lain, seperti isu lingkungan hidup.

Terkait pembuangan, pemerintah menyediakan 29 TPS di empat kecamatan dan satu landfill seluas 5,3 ha di TPA Ngronggo, desa Kumpulrejo, Kecamatan Argomulyo (Diskominfo Kota Salatiga, 2017). Sejak 1994 hingga 2011, landfill TPA Ngronggo dioperasikan dengan menggunakan sistem open dumping, dan tahun 2012 telah ditingkatkan menjadi controlled landfill (Widiasputra et al., 2015). Penggunaan landfill untuk menimbun sampah kota sebenarnya umum dilakukan di negaranegara lain, seperti di Malaysia dan China (Latifah et al. 2009; Zhang et al. 2010). Persoalannya, landfill dengan model open dumping menimbulkan masalah ikutan dalam bentuk air lindi (leachate) yang berisiko mencemari air tanah. Laporan Niko et al. (2015) menunjukkan bahwa kualitas air dari 58 sumur gali di 6 dusun di sekitar TPA Ngronggo berstatus buruk, sementara kualitas air pada 30 sumur gali di 6 dusun yang lain berstatus sedang. Lebih lanjut, Widiasputra et al. (2015) melaporkan bahwa kadar $\mathrm{Cu}^{2+}$ pada $88 \%$ air sumur gali dan kadar $\mathrm{Pb}^{2+}$ pada $72 \%$ air sumur gali di sekitar TPA Ngronggo telah melebihi baku mutu yang ditetapkan oleh pemerintah. Selain itu, studi Widiasputra et al. (2015) menunjukkan bahwa kadar timbal dan tembaga air sumur di dusun yang dekat TPA Ngronggo lebih tinggi ketimbang kadar timbal dan tembaga air sumur yang jauh dari TPA. Studi tersebut mengindikasikan bahwa kontaminasi air sumur penduduk berhubungan dengan produksi air lindi dari TPA Ngronggo dan situasi ini telah dikeluhkan oleh masyarakat di sekitar TPA.

Selain air lindi, landfill merupakan salah satu sumber gas-gas rumah kaca (GRK) yang menyebabkan pemanasan global dan perubahan iklim. Chaerul et al. (2015) melaporkan bahwa di Kendari, landfill merupakan sumber terbesar emisi GRK dengan konsentrasi 50.010 ton $\mathrm{CO}_{2}$ ekuivalen/tahun, diikuti oleh pembakaran sampah yang mengemisikan 340 ton $\mathrm{CO}_{2}$ ekuivalen/tahun, dan pengomposan yang melepas 10 ton $\mathrm{CO}_{2}$ ekuivalen/tahun. Terkait GRK, pemerintah telah mengupayakan distribusi metan $\left(\mathrm{CH}_{4}\right)$ kepada rumah tangga-rumah tangga di sekitar TPA Ngronggo, meskipun optimalisasi masih perlu diusahakan. Walaupun demikian, pengurangan volume sampah tetap harus dilakukan guna meminimalkan emisi GRK. 
Studi ini mengidentifikasi bahwa system pengelolaan sampah di Salatiga banyak diarahkan pada upaya mengatasi sampah (end of pipe) dalam bentuk reuse dan recycle -oleh pemerintah, Bank Sampah, produsen bijih plastik-, insinerasi, maupun penimbunan (landfilling). Al-Salem et al. (2009) menjelaskan bahwa Pengelolaan Sampah Terpadu dibagi menjadi enam kategori yaitu (1) produksi sampah; (2) pemilahan dan pengolahan sampah di sumbernya; (3) pengumpulan; (4) pemisahan dan pemrosesan; (5) penanganan sebelum diangkut ke TPA dan pengangkutan; serta (6) pembuangan. Situasi di Salatiga menunjukkan bahwa pemilahan dan pengolahan sampah di sumbernya atau di rumah tangga masih harus terus diupayakan. Pada saat yang sama, upaya preventif untuk mengurangi produksi sampah plastik masih sangat terbatas, karena kebiasaan menggunakan plastik masih kuat. Beberapa inisiatif ideal pemerintah telah disusun untuk mengoptimalkan pengelolaan sampah, yaitu (1) melaksanakan standarisasi waktu pengolahan sampah; (2) mengubah wewenang pengumpulan sampah yang lebih melibatkan RT, RW, dan kelurahan; (3) meningkatkan public campaign pengumpulan sampah; serta (4) menyiapkan kebijakan dan program kegiatan teknis (Budiana \& Maryono, 2017). Selain itu, pemerintah juga menyusun rencana strategis nasional untuk mengurangi sampah plastik, salah satunya melalui perubahan perilaku (Hendiarti, 2018). Strategi tersebut diperlukan guna membangun kesadaran untuk mengurangi sampah (reduce). Tanpa peningkatan kesadaran lingkungan, timbunan sampah akan tetap tinggi karena laju penyampahan lebih cepat dibandingkan laju pengolahan sampah.

Gambar 5 merupakan model sistem pengelolaan sampah kota Salatiga. Skema tersebut menggambarkan peran masing-masing stakeholder dalam pengelolaan sampah kota. Mengingat bahwa masalah utama jatuh pada kesadaran masyarakat, maka pemerintah berperan untuk memberikan edukasi untuk mengurangi konsumsi plastik dan memilah sampah secara terus menerus kepada masyarakat melalui pelbagai kesempatan, misalnya melalui kegiatan-kegiatan di tingkat RT. Utami et al. (2008) mencatat bahwa himbauan yang berkesinambungan merupakan salah satu faktor yang mempengaruhi partisipasi pemilahan sampah, selain konsistensi system dan ketersediaan fasilitas. Melalui edukasi, masyarakat dapat berpartisipasi secara aktif untuk memilah sampah dan dapat melakukan pengolahan sampah secara mandiri, misalnya mengomposkan sampah-sampah dapur sehingga dapat dimanfaatkan kembali. Mereka dapat berpartisipasi di Bank Sampah sehingga sampahsampah terpilah dapat dijual kepada Bank Sampah atau kepada pemulung untuk sampah non-plastik, mengingat pemulung tidak terlalu berminat mengumpulkan plastik.

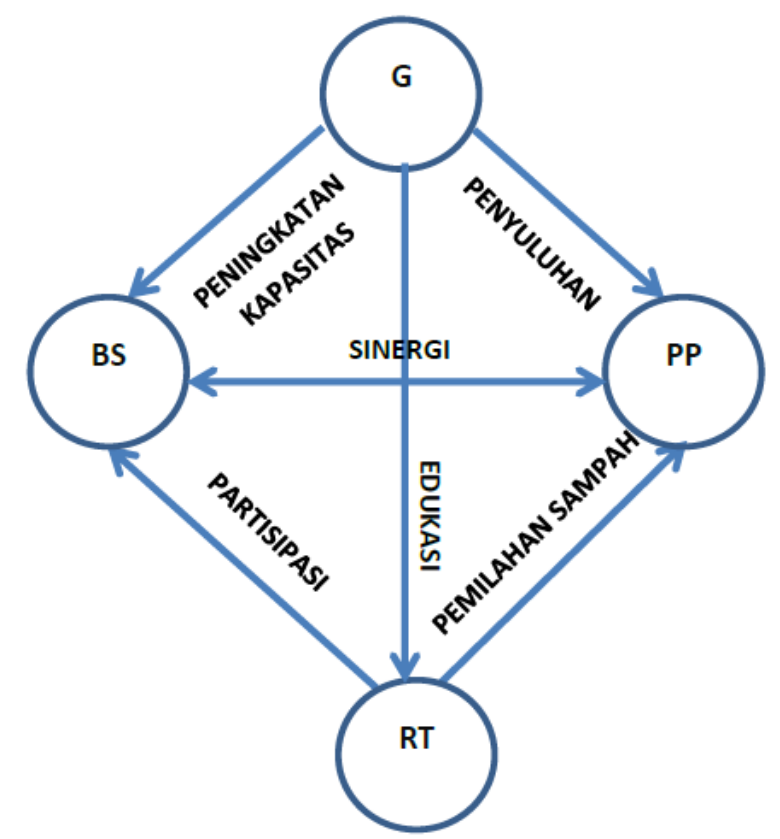

(G: Pemerintah, BS: Bank Sampah, PP: Pemulung-Pengepul, RT: Rumah Tangga)

Gambar 5. Model pengelolaan sampah kota Salatiga

Pemerintah juga berperan untuk meningkatkan kapasitas Bank Sampah melalui kegiatan-kegiatan pelatihan, disamping membangun jejaring dan membantu pemasaran produk-produk Bank Sampah. Dukungan dana sangat mungkin diberikan pada awal berdirinya Bank Sampah hingga Bank Sampah tersebut dapat dilepas sendiri karena sudah berdikari. Perhatian pemerintah juga penting diberikan kepada para pemulung dan pengepul, karena mereka terlibat dalam sistem pengelolaan sampah kota. Zhang \& Wen (2014) menulis bahwa sektor formal dan sektor informal perlu bekerja sama, misalnya pemerintah dapat mempekerjakan pemulung untuk bekerja pada depot pembelian sampah milik masyarakat. Kendati mereka berada pada sektor informal, pemerintah dapat mengelola kelompok pemulung dan pengepul sehingga aktivitas mereka dapat meringankan beban pemerintah. Selain itu, pemerintah juga perlu memberikan penyuluhan ataupun jaminan kesehatan mengingat mereka ini adalah pihak yang berisiko terpapar penyakit karena sehari-harinya berkutat dengan sampah. Bank Sampah dapat menjual sisa sampah yang sudah tidak dapat digunakan untuk membuat produk kerajinan tangan kepada pengepul. Dengan demikian, antara Bank Sampah dan pengepul sampah terjalin kerja sama yang baik dan menguntungkan kedua belah pihak. Akhirnya, sampah-sampah yang tidak dapat diolah lagi, baik oleh Bank Sampah maupun pemulung-pengepul menjadi tanggung jawab pemerintah untuk diolah lebih lanjut atau diabukan.

\section{Kesimpulan}

Sistem pengelolaan sampah plastik di kota Salatiga melibatkan 4 pihak, yaitu rumah tangga sebagai penghasil sampah, pemulung sebagai agen pemilah sampah, Bank Sampah dan pengepul sebagai 
pengolah sampah plastik, serta pemerintah sebagai pengelola sampah kota Salatiga. Upaya pengolahan sampah di Salatiga lebih diarahkan pada penanganan sampah dalam bentuk pakai ulang, daur ulang, dan penimbunan. Upaya mengurangi konsumsi plastik harus berhadapan dengan aspek sosial budaya masyarakat yang belum dapat beralih dari plastik, selain kesadaran lingkungan yang harus terus dipupuk. Peran pemerintah menjadi penting untuk mengedukasi masyarakat supaya dapat memilah sampah dan mengurangi perilaku menyampah, meningkatkan kapasitas Bank Sampah, mengelola pemulung dan pengepul, membangun kerjasama antara 2 pihak tersebut, serta melakukan pengolahan akhir untuk sampah-sampah yang sudah tidak dapat diolah lagi oleh Bank Sampah dan pengepul.

\section{DAFTAR PUSTAKA}

Allaby, M. 2000. Basics of Environmental Science (2nd Ed.). Routledge. London ISBN 0-415-21175-1.

Al-Salem, S.M., O. Lettieri, J. Baeyens. 2009. Recycling and Recovery Routes of Plastic Solid Waste (PSW): A review. Waste Management 29: 2625-2643.

Anderson, D.A. 2010. Environmental Economics and Natural Resource Management ( $3^{\text {rd }}$ Ed). Routledge. New York.

Asia \& M.Z. Arifin. 2017. Dampak Sampah Plastik Bagi Ekosistem Laut. Buletin Matric 14(1): 44-48.

Assuyuti, Y.M., R.B. Zikrillah, M.A. Tanzil, A. Banata, P. Utami. 2018. Distribusi dan Jenis Sampah Laut serta Hubungannya terhadap Ekosistem Terumbu Karang Pulau Pramuka, Panggang, Air, dan Kotok Besar di Kepulauan Seribu, Jakarta. Majalah Ilmiah Biologi Biosfera 35(2): 91-102. Doi: 0.20884/1.mib.2018.35.2.707.

Budiana, M.N. \& Maryono. 2017. Inisiatif Standarisasi Waktu Pengumpulan Sampah di Kota Salatiga. Jurnal Pembangunan Wilayah \& Kota 13(3): 353-367.

Chaerul, M., G.G. Dirgantara, R. Akib. 2016. Prediction of Greenhouse Gases from Municipal Solid Waste Sector in Kendari City, Indonesia. Jurnal Manusia dan Lingkungan 23(1): 42-48.

Dinas Komunikasi dan Informatika (Diskominfo) Kota Salatiga. 2017. Data Pembangunan Kota Salatiga 2016. Pemerintah Kota Salatiga. Salatiga.

Damanhuri, E \& T. Padmi. 2010. Pengelolaan Sampah. Prodi Teknik Lingkungan, Fakultas Teknik Sipil dan Lingkungan, Institut Teknologi Bandung. Bandung.

Guba, E.G. \& Y.S. Lincoln. 1994. Competing paradigms in qualitative research. In N.K. Denzin \& Y.S. Lincoln (Eds). Handbook of Qualitative Research. Sage. Thousand Oaks.

Guerrero, L.A., G. Maas, W. Hogland. 2013. Solid Waste Management Challenges for Cities in Developing Countries. Waste Management 33: 220-232.

Hendiarti, N. 2018. Combating Marine Plastic Debris in Indonesia. Dipresentasikan pada Science to Enable and Empower Asia Pacific for SDGs (Jakarta, 30 Juli 2018).

www.unesco.or.id/publication/SC Retreat/4 Marine DebrisIndonesia.pdf

Jambeck. J.R., R. Geyer, C. Wilcox, T.R. Siegler, M. Perryman, A. Andrady, R. Narayan, K.L. Law. 2015. Plastic waste inputs from land into the ocean. Science 347(6223): 768-771. Doi: 10.1126/science.1260352.

Latifah, A.M., M.A.A. Samah, N.I.M. Zukki. 2009. Municipal Solid Waste Management in Malaysia: Practices and challenges. Waste Management 29: 2902-2906.

Marshall, R.E. \& K. Farahbakhsh. 2013. Systems approaches to integrated solid waste management in developing countries. Waste Management 33: 988-1003.

Nielsen, T.D., K. Horlmberg, J. Stripple. 2019. Need a Bag? A review of public policies on plastic carrier bagsWhere, how, and to what effect? Waste Management 87: 428-440.

Niko, A.I. Kristijanto, S. Hartini. 2015. Status Mutu Air Sumur Gali di Dusun-dusun Sekitar Tempat Pemrosesan Akhir (TPA) Sampah Ngronggo Salatiga dengan Metode STORET. Prosiding Seminar Nasional Kimia dan Pendidikan Kimia Seminar Nasional Kimia dan Pendidikan Kimia "Penguatan Profesi Bidang Kimia dan Pendidikan Kimia melalui Riset dan Evaluasi" (Surakarta, 18 April 2015). ISBN 978-60273159-0-7.

Novianti, A. I. \& L. Kartika. 2017. Pengaruh Green Marketing Kebijakan Kantong Plastik Berbayar Terhadap Green Behaviour Masyarakat Kota Bogor. Jurnal Riset Manajemen dan Bisnis 2(1): 81-94. ISSN 2527-7502.

Purwoko, et. al. 2012. Analisis Efektivitas Pengenaan Cukai atas Produk Kantong Plastik dan Dampaknya Terhadap Perekonomian. Kajian Ekonomi dan Keuangan 16(2): 77-106. ISSN 1410-4239.

Sahwan, F.L., D.H. Martono, S. Wahyono, L.A. Wisoyodharmo. 2005. Sistem Pengolahan Limbah Plastik di Indonesia. J. Tek. Ling P3TL-BPPT 6(1): 311318

Setyowati, R. \& S.A. Mulasari. 2013. Pengetahuan dan Perilaku Ibu Rumah Tangga dalam Pengelolaan Sampah Plastik. Kesmas, Jurnal Kesehatan Masyarakat Nasional 7(12): 562-566.

Singh, P. \& V.P. Sharma. 2016. Integrated Plastic Waste Management: Environmental and improved health approaches. Procedia Environmental Sciences 35: 692-700.

Thompson, R.C., C. J. Moore, F.S. vom Saal, S.H. Swan. 2009. Plastics, the Environment and Human Health: Current consensus and future trends. Phil. Trans. $R$. Soc. B 364: 2153-2166.

Utami, B.D., N.S. Indrasti, A.H. Dharmawan. 2008. Pengelolaan Sampah Rumah Tangga berbasis Komunitas: Teladan dari dua komunitas di Sleman dan Jakarta Selatan. Sodality 2(1): 49-68.

Widiasputra, L.A., A.I. Kristijanto, S. Hartini. 2015. Status Mutu Air Sumur Gali di Dusun-dusun Sekitar Tempat Pemrosesan Akhir (TPA) Sampah Ngronggo Salatiga (Kajian berdasarkan kandungan logam berat $\mathrm{Cu}^{2+}$ dan $\mathrm{Pb}^{2+}$ ). Prosiding Seminar Nasional Kimia dan Pendidikan Kimia "Penguatan Profesi Bidang Kimia dan Pendidikan Kimia melalui Riset dan Evaluasi" (Surakarta, 18 April 2015). ISBN 978-602-73159-0-7.

Zhang, D.Q., S.K. Tan, R.M. Gersbeg. 2010. Municipal Solid Waste Management in China: Status, problems, and challenges. Journal of Environmental Management 91: 1623-1633.

Zhang, H. \& Z.G. Wen. 2014. The Consumption and Recycling Collection System of PET Bottles: A case study of Beijing, China. Waste Management 34: 987998. 